\title{
DEFINICJA MItOŚCI CHRZEŚCIJAŃSKIEJ KLEMENSA ALEKSANDRYJSKIEGO W ŚWIETLE ENCYKLIKI BENEDYKTA XVI ,DEUS CARITAS EST”
}

W greckiej literaturze patrystycznej, wśród wielu ogólnych określeń miłości chrześcijańskiej ( $\alpha \gamma \alpha \dot{\lambda} \eta)$, niełatwo odnaleźć formuły, które by posiadały charakter ściśle definicyjny. W wielkim greckim leksykonie patrystycznym G. W.

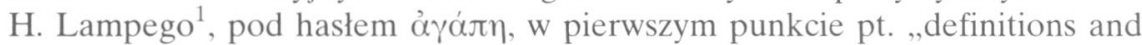
order", znajdujemy odsyłacze jedynie do dwóch autorów: Klemensa Aleksandryjskiego ${ }^{2}$ i Grzegorza z Nyssy ${ }^{3}$. Pierwszy z wymienionych autorów, jako wcześniejszy ${ }^{4}$, budzi szczególne zainteresowanie, z tej też racji, że w swych sformułowaniach nawiązuje zarówno do nauki św. Jana i św. Pawła, jak i do określeń stoickich.

Dalszym ważkim przyczynkiem, skłaniającym do podjęcia niniejszego studium, jest ukazanie się 25 grudnia 2005 r. encykliki papieża Benedykta XVI „Deus Caritas est”, w której zostały przedstawione „,niektóre istotne dane na temat miłości, jaką Bóg w tajemniczy i darmowy sposób ofiaruje człowiekowi razem z wewnętrzną więzią tej Miłości, z rzeczywistością miłości ludzkiej"5.

Rodzi się pytanie, na ile nauczanie Klemensa Aleksandryjskiego na temat istoty miłości chrześcijańskiej, weryfikuje się w wykładzie Urzędu Nauczycielskiego Kościoła. Studium niniejsze pragnie dać zwięzłą odpowiedź, na wyżej postawiony problem.

1. Klemensowa definicja miłości chrześcijańskiej agape. W drugim Stromacie, w kontekście rozważań na temat relacji cnót chrześcijańskich między sobą, Klemens Aleksandryjski podaje następującą definicję miłości chrześcijańskiej $(\dot{\alpha} \gamma \alpha \dot{\alpha} \pi \eta)^{6}$ :

${ }^{1}$ Por. A Patristic Greek Lexicon, ed. G.W.H. Lampe, Oxford 1961, 7-8.

2 Por. Stromata II 41, 2, ed. O. Stählin, GCS 52, 134; tamze VII 68, 1-4, GCS 17, 49.

${ }^{3}$ Por. De anima et resurrectione, PG 46, 93C; In Cantica Canticorum hom. 4, PG 44, 845D.

${ }^{4}$ Klemens Aleksandryjski zmarł przed rokiem 215, Grzegorz z Nyssy zmarł w roku 394, por.

F. Drączkowski, Patrologia, Pelplin - Lublin 1998, 112 i 238.

5 Benedictus XVI, Deus caritas est 1, AAS 98 (2006) 218, wyd. Pallottinum, Poznań 2006, 4.

${ }^{6}$ Dalej to określenie wprowadzamy w polskiej transkrypcji - agape. 
„Agape więc byłaby jednomyślnością (ónóvota) w sprawach przynależnych do

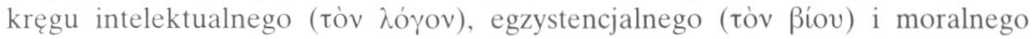

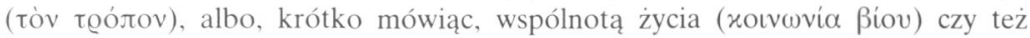

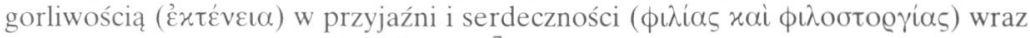
z rozumną troską o potrzeby bliźnich"?

Zanim przejdziemy do szczegółowej analizy powyższej definicji, należy wyjaśnić, że Klemens Aleksandryjski wierny tradycji biblijnej, mówiąc o miłości chrześcijańskiej posługuje się terminem agape. W wyżej cytowanej definicji daje się jednak zauważyć, jak boryka się z właściwym doborem słów i wyrażeń, które oddałyby najbardziej adekwatnie zamierzone treści. Stąd też właściwie podaje trzy określenia agape połączone spójnikiem $\eta$ - albo. Spróbujmy więc wyodrębnić każdy z trzech członów powyższego cytatu, które mogą być traktowane jako trzy odrębne próby definicji, czy też po prostu definicje. Według Klemensa więc miłość chrześcijańska byłaby:

a) ,jednomyślnością w sprawach przynależnych do kręgu intelektualnego, egzystencjalnego i moralnego": terminem definiens jest słowo ,,jednomyślność” (ónóvota);

b) „wspólnotą życia”: terminem definiens jest słowo „wspólnota” (xolvwia);

c) ,gorliwością w przyjaźni i serdeczności razem z rozumną troską o po-

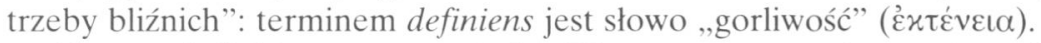

Druga definicja w wypowiedzi Klemensa poprzedzona jest słowami

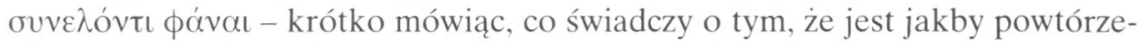
niem tej samej treści za pomocą mniejszej ilości słów, czyli jest po prostu streszczeniem pierwszej definicji. Zatem agape, najkrócej mówiąc, jest „wspólnotą życia”. Z kolei trzecia definicja jest próbą praktycznego przedstawienia, jak należy rozumieć ową , wspólnotę życia”, na którą składa się całokształt spraw przynależnych do sfery intelektualnej, moralnej i egzystencjalnej. Klemens odczuwa jakby pewien niedosyt, który skłania go do trzeciej próby oddania istoty agape za pomocą innych słów. W tym celu ucieka się do znanego

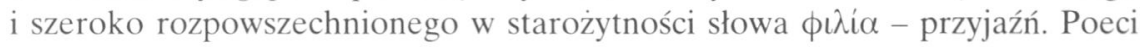
w swych wierszach, filozofowie w rozprawach, sławili wartość i wielkość przyjaźni, zaliczanej do największych dóbr tego świata. Zatem od nieco abstrakcyjnego xoıvwvia, przechodzi Klemens do bardziej znanego i konkretnego, jakim jest słowo $\phi \mathbf{i} \lambda \dot{\alpha} \alpha$.

Reasumując to wszystko, można by więc powiedzieć, że definicja druga jest streszczeniem tak pierwszej, jak i trzeciej. Z owych trzech określeń: ópóvota,

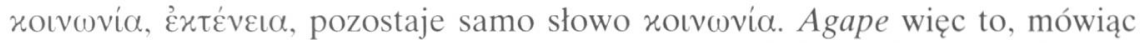
najkrócej, noıvwvía Bíov - wspólnota życia. Słowo ßíos w tym kontekście musi być rozumiane bardzo szeroko, tj. jako życie, tryb życia, sposób życia, środki

\footnotetext{
7 Stromata II 41, 2, GCS 52, 134, tłum. własne.
} 
potrzebne do życia, jednym słowem - całokształt egzystencji duchowo-materialnej ${ }^{8}$. Słowo xoıvwvia, oznaczające w języku greckim „uczestnictwo", „wspólnotę”, „związek”, „połączenie”, „spółkę”, „obcowanie”, „współczucie" ${ }^{9}$, nieodparcie przywodzi na myśl wielość osób, a przynajmniej dwie osoby. Agape więc, będąca „wspólnotą życia”, już z samej swej natury ma charakter społeczny, co Klemens w innym miejscu zupełnie wyraźnie zaznacza, okreś-

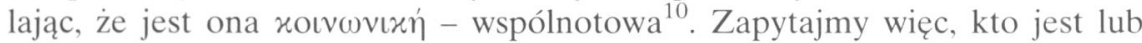
może być partnerem tak rozumianej wspólnoty, czyli zapytajmy o podmiot agape.

Warto zaznaczyć, że Benedykt XVI w swej encyklice „Deus Caritas est” zaznacza, że miłość w miarę dojrzewania i wzrostu przekształca się we wspólnotę sfery uczuciowej, wolitywnej i rozumowej: Idem velle atque idem nolle chcieć tego samego, i nie chcieć tego samego, to właśnie starożytni uznawali za prawdziwą treść miłości: stać się podobnym jedno do drugiego, co prowadzi do wspólnoty (perducit ad communitatem) pragnień i myśli. Historia miłości między Bogiem a człowiekiem polega właśnie na fakcie, że ta wspólnota (communio) woli wzrasta w jedność myśli i uczuć [...]"11.

2. Bóg - rzeczywistym podmiotem agape. W nauce o Trójcy Świętej zwraca uwagę następująca wypowiedź Klemensa:
„Wpatruj się w tajemnice miłości, a wtedy będziesz oglądał łono Ojca, o którym tylko Bóg, Syn jednorodzony, opowiedział. A Bóg sam jest miłością i przez miłość dał się nam poznać. To, co jest w Nim niewypowiedziane, jest Ojcem; to, co z nami współczuje, stało się matką. W Ojcu przez miłość poczęły się cechy niewieście; a wielkim dowodem jest na to Ów, którego Ojciec zrodził z siebie; owoc zaś zrodzony z miłości sam jest miłością. Dlatego też sam zstąpił na ziemię; dlatego stał się człowiekiem; dlatego z własnej woli wycierpiał los człowieczy, aby, przy- jąwszy na siebie miarę niemocy nas - ludzi, których umiłował, udzielić nam w zamian swojej mocy"12.

W powyższym cytacie bardzo wyraźnie zaznaczają się wpływy teologii św. Jana, przede wszystkim zaś jego nauki o miłości chrześcijańskiej. Na szczególną uwagę zasługują słowa: „Bóg jest miłością” (1J 4, 16), przytoczone nieomal dosłownie przez Klemensa oraz powtórzone dosłownie lub w formie sparafrazowanej przy innych okazjach, np. w czwartym i piątym Stromacie, gdzie m.in. czytamy:

${ }^{8}$ Por. H.G. Liddell - R. Scott, Greek-English Lexicon, Oxford 1961 (dalej cyt.: Liddell-Scott), 316: „life, but mode of life, manner of living”.

9 Tamże, 970.

${ }^{10}$ Por. Stromata II 87, 2, GCS 52, 159.

11 Deus caritas est 17, AAS 98 (2006) 231, wyd. Pallottinum, s. 26.

12 Quis dives salvetur 37, 1-2, GCS 17, 183-184, tłum. J. Czuj: Klemens Aleksandryjski, Który czlowiek bogaty może być zbawiony, MBOK 2, Warszawa 1995, 103-104. 


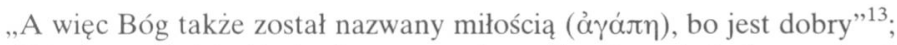

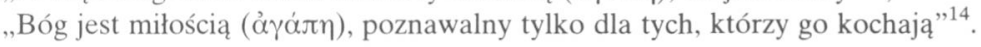

Nie chodzi tu więc o jakieś jednorazowe, okazjonalne cytowanie tego tekstu, ale o świadome eksponowanie pewnej tezy, mianowicie tej, że Bóg w swej najgłębszej istocie jest Miłością, czyli doskonałą wspólnotą Ojca, Syna i Ducha Świętego. Między tymi trzema osobami Trójcy Świętej istnieje doskonała ónóvot $\alpha$ - jednomyślność, jedność, harmonia i zgoda całej egzystencji, czyli doskonała wspólnota życia, tak doskonała i pełna, jak doskonały i pełny pod każdym względem jest Bóg. O tej jedności z Bogiem „tylko Bóg Syn jednorodzony opowiedział" 15 . Podczas ostatniej wieczerzy, na prośbę Filipa: „Panie, pokaż nam Ojca i to nam wystarczy”, Chrystus odpowiedział: „Kto mnie widzi, widzi też Ojca. Jak ty możesz mówić: Pokaż nam Ojca? Czyż nie wierzysz, że Ja jestem w Ojcu i że Ojciec jest we Mnie?” (J 14,8-10). Jakże często na kartach Ewangelii Chrystus mówi o swej miłości do Ojca, o swej jedności z Ojcem, o pełnej harmonii poznania, woli i działania ${ }^{16}$ :

„Gdy podwyższycie Syna Człowieczego, wtedy poznacie, że ja jestem i że nic od siebie nie uczynię, ale mówię to, czego mnie Ojciec nauczył. A ten, który mnie posłał, jest ze Mną. Nie zostawił Mnie samego, bo Ja zawsze czynię to, co się Jemu podoba" (J 8, 28 i 29). Klemens za św. Janem przypomina, że Jezus Chrystus , jest w Ojcu - i jest nazywany sprawiedliwym ze względu na stosunek wzajemnej miłości, która to nazwa oddaje równość ich potęgi"17. Ze zrozumiałych względów relacja Ojciec-Syn zostaje w teologii Klemensa wyeksponowana na pierwszy plan. Jego zafascynowanie Boskim Logosem Wychowawcą i Nauczycielem ludu zbawionego nadaje doktrynie Klemensa zdecydowanie rys chrystologiczny. To zaś z kolei konsekwentnie prowadzi do akcentowania prawdy, że zrodzone z Ojca Słowo jest Synem Bożym. Bóg jest Ojcem. "W Ojcu przez miłość poczęły się cechy niewieście" 18 . Ojciec więc zrodził Syna mając niejako w sobie cechy żeńskie i męskie, które w ludzkim zrozumieniu niezbędne są w procesie prokreacji. Tego rodzaju supozycje, jakie zawarte są w zacytowanym na początku punktu tekście, prowadzą do wyeksponowania prawdy o Bogu jako Ojcu Syna Bożego i wszystkich bytów. Jest to tendencja, jak zauważył J. Lebreton ${ }^{19}$, typowa dla teologii platońskiej i neoplatońskiej.

13 Stromata IV 113, 4 i IV 100, 5, GCS 52, 298-292, thum. J. Niemirska-Pliszczyńska: Klemens Aleksandryjski, Kobierce, I, Warszawa 1994, 360 i 352.

${ }^{14}$ Stromata V 13, 1 i VI 113, 4, GCS 52, 334 i 489, Niemirska-Pliszczyńska II 15 i 180.

15 Quis dives salvetur 37, 2, GCS 17, 184, Czuj s. 104.

16 Por. Theologisches Wörterbuch zum Neuen Testament I-X, red. G. Kittel - G. Friedrich, Stuttgart 1933-1979 (dalej cytuję TWNT), tutaj: I 53.

17 Paedagogus I 71, 3, ed. O. Stählin, GCS 12, 131; J 14, 8-10.

18 Quis dives salvetur 37, 1, GCS 17, 183, Czuj s. 104.

19 Por. La theologie de la Trinité chez Clement d'Alexandrie, RSR 34 (1947) 72. 
Tendencje powyższe nie przesądzają faktu, jakoby Klemens nie posiadał świadomości istnienia Trójcy Świętej. Wręcz przeciwnie, posiadamy teksty, w których wyraźnie prawda ta została potwierdzona. Co więcej, Klemens nawet dopatruje się śladów nauki o Trójcy Świętej u Platona ${ }^{20}$. Zatem określenie, że „Bóg jest miłością”, w interpretacji Klemensa, oznacza, iż Ojciec, Syn i Duch Święty tworzą doskonałą wspólnotę życia polegającą m.in. na pełnej jednomyślności, jedności i harmonii jestestwa Bożego, tak w zakresie poznania, jak też woli i działania. Ponieważ Bóg ze swej natury pod każdym względem jest doskonały, dlatego też ta „wspólnota życia”, czyli Boska agape, musi być także pod każdym względem pełna i doskonała. Stąd też trzy osoby Boskie są rzeczywistym podmiotem agape. Co więcej - są również początkiem i źródłem miłości.

Nawiązując do nauki św. Jana, pod koniec III księgi Pedagoga, jakby w podsumowaniu poprzednich wypowiedzi na temat agape, pisze:

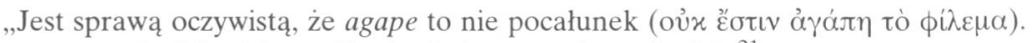

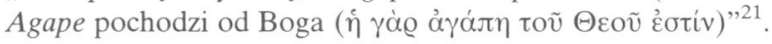

Druga część tego cytatu jest nieomal dosłownym powtórzeniem słów wyjętych

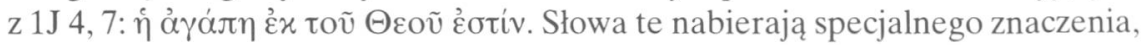
ze względu na kontekst, w którym zostały wypowiedziane. Określenie uczt chrześcijańskich słowem agape, Klemens zwalczał ${ }^{22}$. Jak się okazuje, zastrzeżenia jego nie ograniczały się tylko do nomenklatury. Dalsza sprawa, która go raziła, to zwyczaj przesadnego obdarowywania się pocałunkami pokoju podczas wspólnych spotkań na ucztach chrześcijańskich:

„Niektórzy bowiem nie czynią nic innego, jak tylko napełniają kościoły odgłosem pocałunków, nie mając wewnątrz miłości" ${ }^{23}$.

W tym kontekście powtórnie pada stwierdzenie: ,agape to nie pocałunek” ${ }^{24}$. Klemens w ogóle wyraża wątpliwość, czy tak nadmierne całowanie się spełnia funkcję symbolu i znaku, czy też staje się celem samym w sobie na gruncie sympatii i pociągu, jaki czują do siebie dwie osoby. Jeśliby tak było, to nie ma to nic wspólnego z prawdziwą chrześcijańską agape, lecz jest tylko wyrazem erotycznego czy seksualnego pociągu, czy po prostu ludzkiej sympatii, jaką odczuwają względem siebie różne osoby ${ }^{25}$. W VI Stromacie Klemens bardzo

${ }^{20}$ Por. Stromata V 102, 5-103, 1; zob. J 1, 3.

21 Paedagogus III 82, 2, GCS 12, 281, tłum. własne.

22 Por. tamże II 4, 4; 5, 4; 6, 1-2; zob. K. Völker, Mysterium und Agape, Wien 1927, 153.

23 Paedagogus III 81, 2, GCS 12, 281, tłum. własne.

${ }^{24}$ Tamże. A. Nygren (Erôs et agapè. La notion chrétienne de l'amour et ses transformations, tłum. franc. P. Jundt, I/2, Paris 1944, 152) kwestionuje, czy uczty chrześcijańskie rzeczywiście zasługiwały aż na tak surową krytykę ze strony Klemensa.

25 Por. Paedagogus III 81, 3-4. 


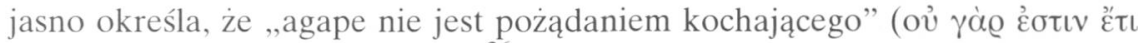

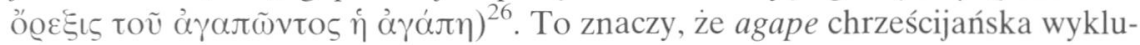
cza moment zmysłowej przyjemności. Słowo ő@e $\xi ı 5$ oznacza „naturalną skłon-

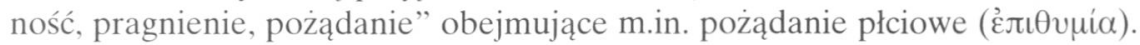

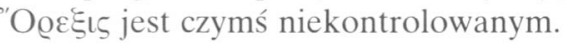

Chrześcijańska agape ma swój punkt odniesienia, jakim jest doskonała wspólnota trzech osób Boskich: Ojca, Syna i Ducha Świętego. Tylko podłączenie się do tej wspólnoty daje udział w prawdziwej miłości chrześcijańskiej, która „pochodzi od Boga"27. Trójca Święta jest więc źródłem i początkiem chrześcijańskiej miłości. Ta Boska miłość jest czymś nadrzędnym i wyższym w stosunku do tej, która bywa osiągana przez ludzi i zawsze jeszcze może się doskonalić. Należy dodać, że Benedykt XVI akcentuje prawdę o boskim charakterze i boskim źródle miłości. Pod koniec pierwszej części swej encykliki zamieszcza zwięzłe stwierdzenie: „Miłość jest «Boska», ponieważ pochodzi od Boga i łączy nas z Bogiem (Amor «divinus» est, quoniam ex Deo procedit isque nos cum Deo coniungit)"28. To zdanie jest jakby refleksem Klemensowego stwierdzenia, że miłość - agape jest Boska $(\theta \varepsilon \tilde{\imath} \alpha)^{29}$; jest do Boga prowadząca

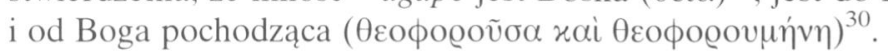

3. Człowiek potencjalnym podmiotem agape. Jezus Chrystus, Boski Logos, trwający w doskonałej wspólnocie życia z Ojcem i Duchem Świętym, Bóg zrodzony z Boga, który jest miłością. Jako „owoc zrodzony z miłości sam jest miłością. Dlatego też sam zstąpił na ziemię; dlatego stał się człowiekiem"31. Motywem wcielenia była Boska Miłość. Chrystus-Bóg, uosobiona Miłość, przybył do nas na ziemię i dał nam swoją miłość. W tym kontekście nabierają pełnego waloru słowa św. Jana, powtórzone przez Klemensa: „miłość ( $\gamma \gamma \alpha \dot{\pi} \eta)$ pochodzi od Boga ${ }^{32}$. Chrystus, Miłość uosobiona, pochodzi od Boga, bo sam jest Bogiem. Chrystus przyjmując postać człowieka z miłości do nas, sam niejako pierwszy wyszedł z propozycją włączenia nas, ludzi, do wspólnoty swego Boskiego Życia, które ma z Ojcem i Duchem Świętym. Bóg, jako realizacja doskonałej wspólnoty życia, jest więc jedyną szansą człowieka do wyniesienia go na wyżyny Boskiego bytowania. Od wolnej woli ludzkiej uzależnione jest wykorzystanie lub niewykorzystanie tego Bożego zaproszenia.

26 Stromata VI 73, 3, GCS 52, 468.

27 Paedagogus III 82, 1; 1J 4, 7. Agape pochodzi od Boga i jest istotą Boga, por. B. Vawter, Le epistole Giovanee, w: Grande Commentario Biblico, Brescia 1973, 1361: „Dio è amore: L'amore non solo viene da Dio come dalla sua fonte, ma è la stessa essenza di Dio".

${ }^{28}$ Deus caritas est 18, AAS 98 (2006) 232, wyd. Pallottinum, s. 28.

29 Por. Stromata V 13, 2.

${ }^{30}$ Por. Stromata VI 104, 1.

31 Quis dives salvetur 37, 2-3, GCS 17, 184, Czuj s. 104

32 Por. Paedagogus III 82, 2; 1J 4, 7; zob. też Quis dives salvetur 37, 4. 
Kto zdecyduje się na udział we wspólnocie Bożego życia, nie od razu osiągnie jej pełnię. Przez chrzest, w momencie wstąpienia na drogę doskonalenia człowiek posiada w sobie zaczątek Bożego życia, ,zarodek” agape, który ma rosnąć i dojrzewać. Osiągnięcie jednak pełni doskonałej miłości, na miarę Bożej doskonałości, w obecnym ziemskim bytowaniu jest dla człowieka rzeczą prawie niemożliwą. Człowiek pozostaje stale potencjalnym podmiotem Bożej miłości, która jedynie jest pełna i pod każdym względem doskonała.

Jeśli wiele osób pozytywnie odpowie na zaproszenie do Bożej wspólnoty Życia, do prawdziwej miłości, i zwiąże się z życiem Trójcy Świętej, tym samym wytworzy się między nimi wspólnota i łączność, którą można określić nazwą miłości. Dostęp do Boga mamy za pośrednictwem Chrystusa, stąd też stopień wszczepienia w Chrystusa jest probierzem intensywności naszej miłości. Chrystus powiedział o sobie: „Ja jestem prawdziwym krzewem winnym [...]. Pozostańcie złączeni ze Mną, a Ja z wami. Jak latorośl sama nie może przynosić owocu, jeśli nie jest złączona $z$ winnym krzewem, tak wy nie możecie przynosić owocu, jeśli nie jesteście ze Mną złączeni (J 5, 1. 4)". Chrystus powiedział do

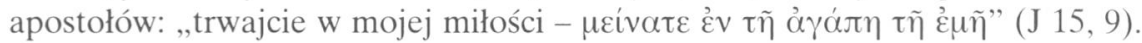
Nie powiedział: „miłujcie Mnie”, lecz „trwajcie w mojej miłości”, tj. trwajcie w tej wspólnocie, którą ja posiadam z Ojcem i Duchem Świętym. „Trwajcie” należy rozumieć jako „trwajcie wzrastając ustawicznie” na miarę dojrzałości Bożej. Św. Paweł określił to jeszcze dokładniej, kiedy wzywał swoich wiernych do wzrostu na miarę dojrzałości Chrystusowej (Ef 4,13), co oznacza dojrzewanie do prawdziwego życia Trójcy Świętej. Zdaniem Klemensa, „nie znać Boga - to nie żyć, a znać i obcować z Nim, miłować Go i upodabniać się do Niego - to

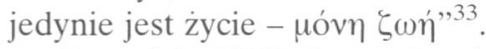

Benedykt XVI akcentuje również w swej encyklice, że miłość człowieka pozostaje na etapie ciągłego wzrostu: „Jest to jednak proces, który pozostaje w ciągłym rozwoju: miłość nigdy nie jest «skończona» i spełniona, miłość zmienia się wraz z biegiem życia, dojrzewa i właśnie dlatego pozostaje wierna samej sobie" $" 34$.

\section{4. ,Jednomyślność w sprawach przynależnych do kręgu intelektualne-}

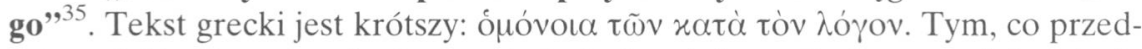
łuża polskie tłumaczenie, jest rodzajnik dopełniacza liczby mnogiej rodzaju nijakiego, który oddajemy za pomocą czterech polskich słów: „spraw przynależnych do kręgu". Rodzajnik $\tau \tilde{\omega} v$ dobrze oddano w łacińskim przekładzie zamieszczonym u Migne'a ${ }^{36}$ za pomocą zwrotu: „,eorum quae sunt”. Jak wia-

\footnotetext{
33 Quis dives salvetur 7, 3, GCS 17, 164, Czuj s. 54.

${ }^{34}$ Deus caritas est 17, AAS 98 (2006) 231, wyd. Pallottinum, s. 26.

35 Stromata II 41, 2, GCS 52, 134.

${ }^{36}$ Por. Stromata II 41, 2, PG 9, 975C.
} 
domo, zaimek liczby mnogiej rodzaju nijakiego nadaje całej wypowiedzi bar-

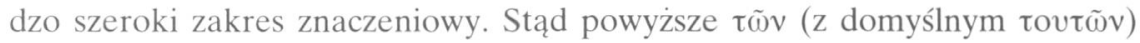
można by też przetłumaczyć jako: „tych wszystkich rzeczy z dziedziny” albo „wszystkiego, co wiąże się ze sprawami przynależnymi do”, albo „całokształtu spraw i problemów z zakresu” itd. W konsekwencji również dalsze słowa ( $x \alpha \tau \dot{\alpha}$

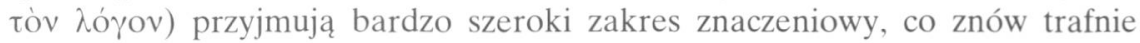
oddano u Migne’a za pomocą słów ,in ratione”. Cały zwrot „eorum quae sunt in ratione" idzie po linii tej samej, co wyżej podane polskie tłumaczenie: „W sprawach przynależnych do kręgu intelektualnego". Wpływa na to również użyte tu słowo $\lambda$ ójos, przyjmujące wielką ilość znaczeń. Najbardziej znane $\mathrm{z}$ nich to: sprawozdanie, zestawienie, rachunek ${ }^{37}$; miara, ilość, liczba, wielkość; stosunek, zgodność, proporcja; podstawa, zasada, motywacja, relacja; teoria, argument; uzasadnienie, sens, wyjaśnienie; sąd, przesłanka, wniosek; zasada, reguła; prawo, zasada postępowania, hipoteza; określenie, pojęcie; ład, porządek, myślenie, rozumowanie; zdolność myślenia; bajka, legenda; mowa, przemówienie; słowo; dyskusje, dysputa, narada; przysłowie, sentencja; sprawa, kwestia; treść utworu; mądrość Boża; Chrystus ${ }^{38}$. Najogólniej rzecz biorąc, słowo $\lambda$ ó $\gamma$ os wiąże swoje znaczenia z funkcjami umysłu ludzkiego, tj. rozumowaniem i myśleniem oraz znakiem zewnętrznym tych funkcji, którym jest słowo. O szczegółowym znaczeniu decyduje kontekst. Ponieważ w naszym wypadku Klemens zamierzał podać definicję, czyli coś, co wchodzi w krąg znaczeń ogólnych, stąd też powyższe tłumaczenie wydaje się w pełni

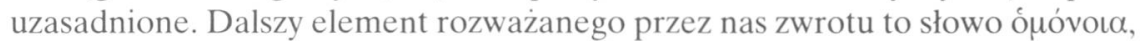
które oznacza: ,jednomyślność, zgodę"39. Pokrewny mu czasownik ónovoéw znaczy: „być jednej myśli, zgadzać się; żyć zgodnie z kimś”40. Rzeczownik

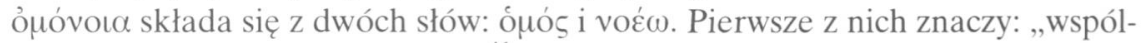
ny, złączony, ten sam, podobny” "41; drugie znaczy: „pojąć, zrozumieć, poznać; myśleć, rozważać; przypuszczać, sądzić, mniemać; wymyślić, uknuć, powziąć; znaczyć, mieć sens" "42. Zatem ó ${ }^{2}$ óvot $\alpha$ to zgodność sądów, wspólnota myślenia, podobieństwo pojmowania. W rozważanym przez nas tekście słowo to oznacza harmonię i zgodę wszystkich spraw przynależnych do ludzkiej sfery intelektualnej z Boskim intelektem, rozumem, mądrością i poznaniem.

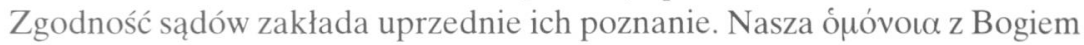
to uzgodnienie naszych sądów, naszego myślenia, naszych zamierzeń z tym, co tkwi w mądrości i poznaniu Trójcy Świętej. To, co zawiera Boski intelekt,

37 Por. TWNT IV 103

38 Por. Stownik grecko-polski, red. Z. Abramowiczówna, I-IV, Warszawa 1958-1965 (= Abramowiczówna), tutaj III 43-46; Liddell-Scott 1057-1059; TWNT IV 126-134.

39 Por. Abramowiczówna III 282; Liddell-Scott 1226: „oneness of mind, unanimity, concord”.

${ }^{40}$ Por. Abramowiczówna III 282; Liddell-Scott 1226.

41 Por. Abramowiczówna III 283; Liddell-Scott 1227: „one and the same, common, jointę.

42 Por. Abramowiczówna III 211; Liddell-Scott 1177. 
poznajemy głównie dzięki Synowi. To, co objawił Chrystus - Boski Logos, to w głównej mierze nauka wiary, zawartej w obu Testamentach, chociaż nie tylko. Boski Logos, druga osoba Trójcy Świętej, działał już przed swoim wcieleniem jako Słowo Ojca. On to dał Grekom filozofię, a Hebrajczykom Prawo (vómos). Wszelka autentyczna mądrość i wiedza, wszelka prawda i umiejętność od Niego pochodzą ${ }^{43}$. Dlatego Klemens nazwał całą paideię helleńską trzecim Testamentem. Zatem wszelka autentyczna mądrość ludzka jest odblaskiem Bożej Mądrości. Naszym zadaniem jest ustawiczne dążenie do poszerzania tej wspólnoty myślenia i poznawania z Boskim intelektem. 'O $\mu$ óvol $\alpha$ w prak-

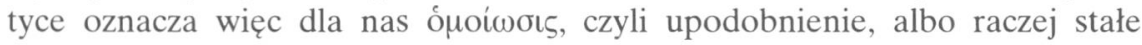
upodobnianie się do Boga i to głównie w zakresie sfery poznawczej. W nauce

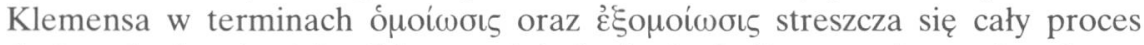
doskonalenia człowieka. Idea upodobniania się do Boga - tak szeroko eksponowana w filozofii platońskiej, a potem w stoickiej - stała się osią całej etyki Klemensa ${ }^{44}$. Według niego bowiem:

„naszym najwyższym celem jest upodobnienie się ( $\hat{\varepsilon} \xi o \mu o i \omega \sigma \iota \varsigma)$ do prawdziwego Logosu, o ile to jest tylko możliwe, oraz za pośrednictwem Syna powrót do doskonałego synostwa, pełnego czci wieczystej dla Ojca za pośrednictwem Wielkiego Arcykapłana (tj. Chrystusa; por. Hbr 4, 14), który nas zaszczycił nazwą braci i współdziedziców" ${ }^{45}$.

To upodobnienie dotyczy całego człowieka, tj. wszystkich jego władz, w tym intelektualnej na tyle, na ile człowiek, jako istota myśląca, posiada rozumność jako pierwiastek konstytutywny i dominujący ${ }^{46}$. Stąd doskonały chrześcijanin, czyli gnostyk, który osiągnął szczyt poznania, czyli gnozę:

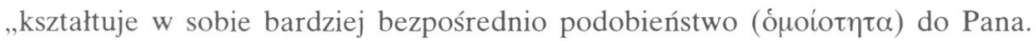

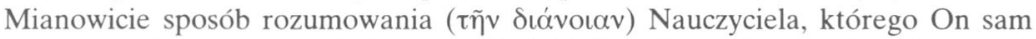
przestrzegał w swym myśleniu i doradzał $(\mathrm{J} 13,15)$ ludziom mądrym i rozważnym, pojmuje tak, jak Pan uczący pragnął $[\ldots]^{3,47}$.

43 W koncepcji Klemensa Chrystus - „światło prawdziwe, odwieczna Mądrość”, ,którą radował się wszechmogący Bóg” (Prz 8, 30; Stromata VII 7, 4), Logos, który „,cały jest myślą, cały jest światłem pochodzącym od Ojca”, ,,mądrością i wiedzą, i wszystkim cokolwiek z tymi pojęciami jest spokrewnione” - dał filozofię po to, by ,prowadziła żywioł helleński do Chrystusa, podobnie jak Prawo dał Hebrajczykom" (Stromata IV 155, 5; VII 6, 4; por. też I 26, 2; 27, 1; 47, 4; 88, 8; 100, 1).

${ }^{44}$ Można mówić tu o wpływie tak idei platońskich, jak i koncepcji biblijnych, por. M. Berciano, Kairos. Tiempo humano e historico-salvifico en Clemente de Alejandria, Burgos 1976, 212 i 251 .

45 Stromata II 134, 2, GCS 52, 187, Niemirska-Pliszczyńska I 218; Hbr 2,12; Rz 8, 17; por. Stromata III 69, 3 .

46 Według Klemensa (Stromata IV 149, 6, GCS 52, 509, Niemirska-Pliszczyńska I 380) „co jest korzystne dla elementu bardziej dominującego w nas, to raczej powinniśmy wybierać, a elementem najbardziej w nas dominującym jest rozum".

47 Stromata VI 115, 1, GCS 52, 489, Niemirska-Pliszczyńska II 181. 
Upodobnienie do Boga to również dążenie do zdobycia tej wiedzy, jaką Bóg posiada:
„Każdy bowiem, kto żyje w niewiedzy ( i popiołem. Kto natomiast osiągnął poznanie, upodobniając się do Boga ( i dlatego wybranym" $"$.

Można więc powiedzieć, że to wszystko, co mieści się w programie owej kształcenia intelektualnego, czyli zdobywanie umiejętności czytania i pisania, pozna-

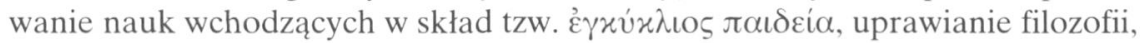
osiąganie prawdziwej mądrości i gnozy, to wszystko razem oznacza realizację postulatu upodobniania się do Boga; oznacza to osiąganie owej jednomyślności i harmonii w sferze spraw przynależnych do dziedziny intelektualnej, czyli tego,

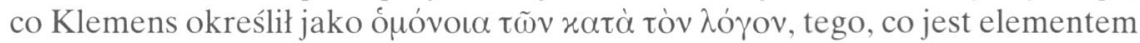
konstytutywnym chrześcijańskiej miłości. Pierwszorzędnym więc przedmiotem agape jest cała sfera intelektualna, ściślej mówiąc - stan (a w wypadku człowieka dążenie do tego stanu) pełnej zgodności sądów, wspólnoty myślenia, podobieństwa pojmowania podmiotów agape, tj. trzech osób Boskich i tych ludzi, którzy osiągnęli pełną doskonałość, czyli ,„jednomyślność w sprawach przynależnych do kręgu intelektualnego".

\section{Jednomyślność w sprawach przynależnych do kręgu obyczajowego:}

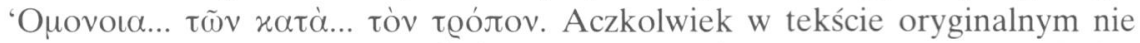

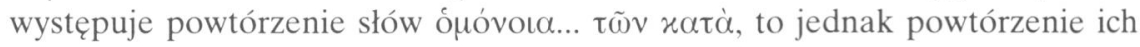
tu wydało się konieczne w celu lepszego uchwycenia logiki wewnętrznej występującej w definicji, która ze względów stylistycznych została podana w formie

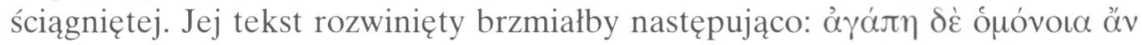

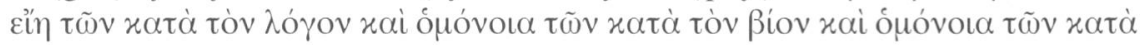

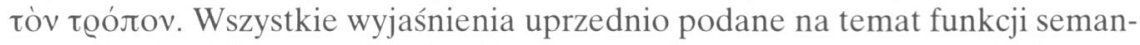
tycznej rodzajnika genetivi pluralis neutrum tòv w tym samym stopniu dotyczą również omawianego tu członu definicji. Zatem odgrywające tu centralną rolę

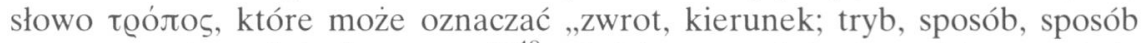
postępowania; tryb życia, zwyczaj" ${ }^{49}$, tak jak poprzednio słowo $\lambda$ ó $\gamma$ o bardzo szeroki zakres znaczeniowy. W łacińskim przekładzie zamieszczonym

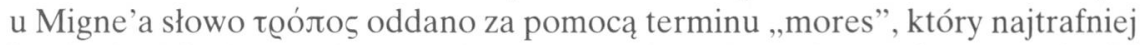
i najzwięźlej określa, że chodzi tu o całą sferę obyczajową, sferę moralności chrześcijańskiej. Obok wspomnianej wyżej ,,jednomyślności w sprawach przynależnych do kręgu intelektualnego" równorzędnym przedmiotem agape jest więc ófóvola, czyli zgodność i harmonia życia moralnego podmiotów uczestni-

48 Stromata IV 168, 2, GCS 52, 323, Niemirska-Pliszczyńska I 392; por. Plato, Teajtet, 176 B.

49 Por. Abramowiczówna IV 363; Liddell-Scott 1827: „tum, direction, way; commonly, way, manner, fashion, guise". 
czących we wspólnocie życia - agape. W praktyce oznaczać to będzie dążenie do zharmonizowania naszej woli $\mathrm{z}$ wolą Boga, czyli po prostu realizowanie programu formacji moralnej, od nawrócenia ( $\mu \varepsilon \tau \dot{\alpha} v o \iota \alpha)$ poprzez etap bojaźni

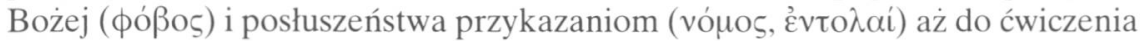

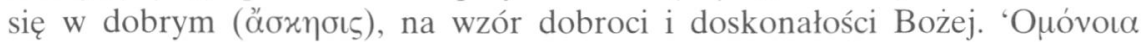

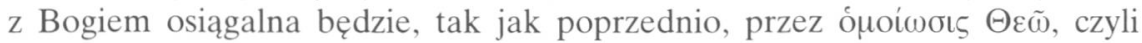
przez upodobnienie się do Boga w zakresie całokształtu życia moralnego.

Dla Klemensa, który zdecydowanie ulegał wpływom stoickim ${ }^{50}$ ważnym elementem życia moralnego była powściągliwość i wolność od afektów. Dlatego człowiek o stałym charakterze dążyć powinien, według niego, „w sposób usilny do upodobnienia się do Boga poprzez cierpliwość w praktykowaniu

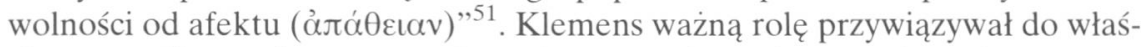
ciwego realizowania etapu posłuszeństwa przykazaniom, posłuszeństwa opartego na bojaźni Bożej. Konsekwencją tego poglądu będzie opinia:

„funkcję zbawczą pełni każdy, kto upodabnia się do Zbawiciela w tym stopniu, w jakim tylko możliwe jest dla ludzkiej natury wymodelować obraz Boga w sobie, wypełniając w sposób wierny to wszystko, co wynika z boskich przykazań” ${ }^{52}$.

Do cnót bardziej eksponowanych przez Klemensa należy pobożność i sprawiedliwość. Na kanwie wypowiedzi 1Kor 11, 1: „Stańcie się moimi naśladowcami, tak jak ja stałem się naśladowcą Chrystusa", twierdzi Klemens, że św. Paweł jako cel wiary zakłada upodobnienie się do Boga, tzn. „w stopniu, jaki tylko do osiągnięcia byłby możliwy, stać się sprawiedliwym, pobożnym a jednocześnie rozumnym" ${ }^{3}$. To zestawienie cytatów jest nader wymowne jako ilustracja Klemensowej nauki o duchowym pokrewieństwie filozofii helleńskiej z doktryną chrześcijańską oraz jako dowód, że idea upodobnienia do Boga wspólna jest tak adeptom wywodzącym się z kręgu kultury helleńskiej, jak i chrześcijanom ${ }^{54}$. Co więcej, Klemens twierdzi, że w tradycji starotestamentowej idea ta była również dobrze znana, aczkolwiek innymi słowy określana. W V Stromacie czytamy na ten temat:

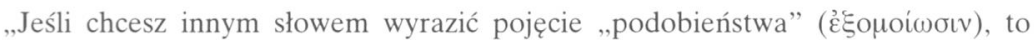
możesz znaleźć u Mojżesza nazwę dla niego, jako «towarzyszenie Bogu». Mówi bowiem: «Podążajcie za Panem, Bogiem waszym, i Jego przykazań przestrzegaj-

${ }^{50}$ Zdaniem niektórych uczonych wpływy stoickie bardziej uwypukliły się w doktrynie Klemensa niż platońskie i neoplatońskie, por. J. Hashagen, Über die Anfänge der Christlichen Staats und Gesellschaftsanschauung, ZKG 49 (1930) 149.

51 Stromata II 103, 1, GCS 52, 169, Niemirska-Pliszczyńska I 198; por. Stromata II 105, 3 - 110, 1.

52 Stromata VI 77, 5, GCS 52, 470, Niemirska-Pliszczyńska II 157.

53 Stromata II 136, 5-6, GCS 52, 188, Niemirska-Pliszczyńska I 220; por. Plato, Teajtet, 176B.

${ }^{54} \mathrm{Na}$ ten temat zob. F. Baravalle, Il concetto di „Homoiosis Theo” in Clemente Alessandrino, Torino 1952; H.I. Marrou, Morale et spiritualité chrétiennes dans le Pédagogue de Clément d'Alexandrie, TU 64 , Berlin 1957, 545. 
cie» (Pwt 13, 4). Towarzyszami i czcicielami Boga są więc ludzie utrwaleni w cnocie" $" 55$.

Ojciec święty traktuje łącznie elementy przynależne do sfery intelektualnej $\mathrm{z}$ aspektami moralno-wolitywnymi. W jego wykładzie miłość Boga do człowieka jest priorytetowo akcentowana. Przypomina, że „Bóg pierwszy nas umiłował i nadal nas kocha jako pierwszy"56. Człowiek odpowiadając pozytywnie na tę „propozycję” może spotkać się z Bogiem w miłości. „To spotkanie wymaga jednak również zaangażowania naszej woli i naszego intelektu (Sed hic occursus nostram etiam voluntatem intellectumque involvit). Rozpoznanie Boga żyjącego jest drogą wiodącą do miłości, a «tak» naszej woli na Jego wolę łączy rozum, wolę i uczucie (intellectum, voluntatem et affectionem) w ogarniający wszystko akt miłości (in amoris actu) ${ }^{\prime 57}$.

\section{6. „Jednomyślność $w$ sprawach przynależnych do kręgu egzystencjal-}

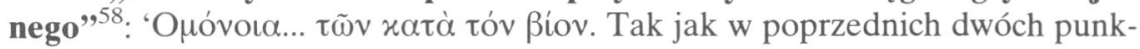

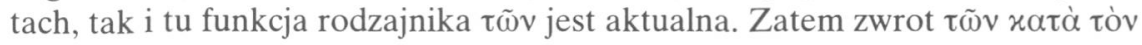
ßíov przyjmuje bardzo szeroki zakres znaczeniowy. Słowo ßíos, oznaczające: życie, sposób, tryb życia; życie biologiczne; czas, trwanie życia; środki do życia, żywność; świat; życie osiadłe ${ }^{59}$, w powyższym kontekście oznacza całokształt spraw przynależnych do egzystencji podmiotów uczestniczących w agape, co w wypadku ludzi oznacza również całokształt spraw praktycznych przynależ-

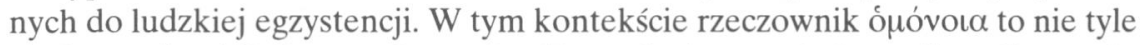
„,jednomyślność”, ile raczej „zgodność, zgoda, harmonia i wspólnota” w praktycznych kwestiach życiowych. Fakt ten jest prostą konsekwencją poprzednich dwóch elementów, omówionych w powyższych dwóch punktach, tzn. jednomyślności i harmonii w sferze poznawczej i wolitywnej. Jeśli jakieś osoby osiągną porozumienie, co więcej - zharmonizują swoje myślenie i uzgodnią poglądy, efektem tego wydarzenia i logiczną konsekwencją będzie podjęcie wspólnych decyzji i postanowień, które powinny zostać zrealizowane, czyli wprowadzone w czyn. Powstaje trójczłonowy ciąg: myśl $\Rightarrow$ decyzja $\Rightarrow$ czyn, którego poszczególne elementy oddają najzwięźlej to, co rozwinięte jest w niniejszych trzech punktach.

Co rozumie Klemens przez całokształt spraw przynależnych do życia praktycznego i działania? Jak już wspomniano w pierwszym punkcie, Klemens podał jakby trzy definicje agape, które w istocie rzeczy sprowadzają się do

55 Stromata V 94, 6, GCS 52, 388, Niemirska-Pliszczyńska II 75; por. Philo Alexandrinus, De migratione Abrahami 127 (131).

56 Deus caritas est 17, AAS 98 (2006) 231, wyd. Pallottinum, s. 25.

57 Tamże, wyd. Palottinum, s. 26.

58 Stromata II 41, 2, GCS 52, 134.

59 Por. Abramowiczówna I 426; Liddell-Scott 316. 


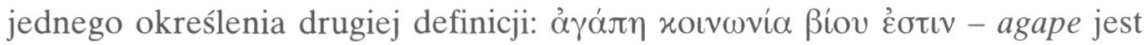
wspólnotą życia. Jak należy rozumieć ową wspólnotę życia - na gruncie teoretycznym wyjaśnia pierwsza definicja; na gruncie praktycznym zaś trzecia definicja, kiedy określa agape jako gorliwość w przyjaźni i serdeczności wraz

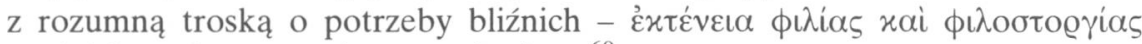

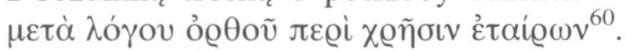

Słowo фı $\lambda i \alpha$ oznacza nie tylko przyjaźń, ale też oznaczać może „zażyłość”,

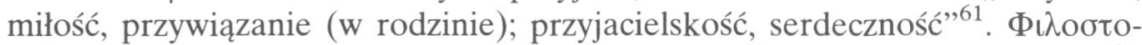

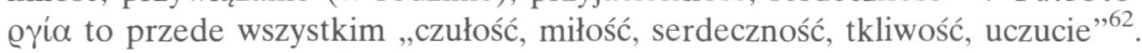

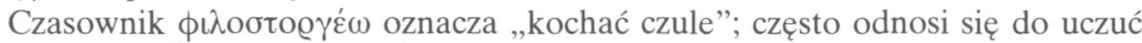

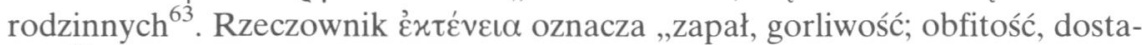

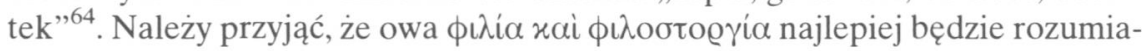
na w analogii do uczuć, jakie wiążą członków jednej rodziny. Sam Bóg Ojciec nazywając Boski Logos swoim Synem sięgnął do relacji występujących w kręgu rodziny. Agape więc, na płaszczyźnie egzystencjalnej, jest pewnego rodzaju związkiem uczuciowym, który wiąże ludzi przebywających z sobą, jak to ma miejsce w przypadku rodziny, która łączy osoby razem mieszkające i wspólnie spożywające posiłki. Zatem sfera uczuciowa natury ludzkiej też partycypuje w agape. Zresztą już wcześniej zauważono, że agape obejmuje całego człowie$\mathrm{ka}$, a więc sferę intelektualną, wolitywną i uczuciową ${ }^{65}$, co w niniejszej pracy znalazło swoje potwierdzenie. Nie należy jednak zapominać, że Klemens miał na uwadze sferę uczuciową całkowicie oczyszczoną ze wszystkiego, co dotyczy-

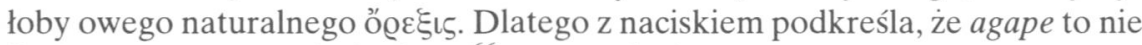

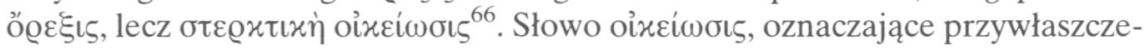
nie; pokrewieństwo, skłonność, popęd, pociąg do czegoś, bliskie stosunki, zażyłość, poufałość z kimś" ${ }^{67}$, nieodparcie kojarzy się z rzeczownikiem oĩxos dom, mieszkanie, i czasownikiem oixź $\omega$ - zamieszkiwać. Cała ta grupa wyrazów związana z czymś, co jest najbardziej elementarne dla życia ludzi, tj. z ich mieszkaniem, domem, siedzibą, implicite zawiera prawdę o fakcie zżycia się i zgrania tych osób, bardzo często dodatkowo związanych więzami krwi. Ta

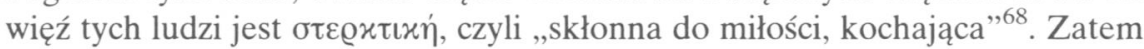

${ }^{60}$ Stromata II 41, 2, GCS 52, 134, Niemirska-Pliszczyńska I 157.

61 Por. Abramowiczówna IV 519.

${ }^{62}$ Por. tamże, s. 531; Liddell-Scott 1940.

${ }^{63}$ Por. Abramowiczówna IV 531; Liddell-Scott. 1940: „love tenderly, freg. of family affection".

${ }^{64}$ Por. Abramowiczówna II 84; Liddell-Scott 521: „zeal, assiduousness”.

${ }^{65}$ Por. A. Freine, Eros platonicien et agapè chrétienne, „Annale Universitatii Bucuresti. Serie Limbi Clasice si Orientale" 22 (1973) 23-35.

${ }^{66}$ Por. Stromata VI 73, 3, GCS 52, 468.

67 Por. Abramowiczówna III 247; Liddell-Scott 1202: „appropriation, affinity, attraction, affection".

${ }^{68}$ Por. Abramowiczówna IV 103; Liddell-Scott 1640: „disposed to love, affectionate”. 


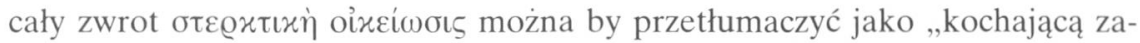
żyłość” lub też „pełne duchowego ciepła zbliżenie”. I w tym wypadku relacje występujące w dobrze funkcjonującej i kochającej się rodzinie najlepiej odzwierciedlają związki uczuciowe występujące między podmiotami agape.

Głównym podmiotem agape jest Trójca Święta. Nasze włączenie się do tej wspólnoty życia osób Boskich wiąże się z naszym zaprzyjaźnieniem się z Bogiem, z ,zadomowieniem” się w Nim, z uzyskaniem owej oixzíwoıs. Analogicznie do relacji między ludźmi, którzy poprzez przebywanie z sobą, poprzez wzajemne kontakty i rozmowy coraz bardziej się zżywają i pogłębiają swoją przyjaźń, nasza więź z Boską wspólnotą życia będzie się zacieśniała i rosła za pośrednictwem naszych kontaktów z Bogiem. Wśród nich podstawową rolę pełni modlitwa, czyli rozmowa z Bogiem, bo tak właśnie Klemens - jako pierwszy - określił modlitwę. Jest to najbardziej znane i najczęściej cytowane

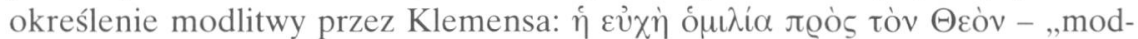
litwa jest rozmową z Bogiem"69.

Należy jednak zaakcentować, że wyrywanie powyższej definicji z jej kontekstu oraz kurczowe trzymanie się samej egzegezy słowa homilia wraz z jego analogiami u innych autorów, jak to uczynił E. Von Severus ${ }^{70}$ nie prowadzi do wyjaśnienia istoty modlitwy u Klemensa. Wyżej wspomniana definicja wraz z jej kontekstem brzmi:

„Jest zatem modlitwa, żeby się wyrazić tak zuchwale, rozmową z samym Bogiem. Choćbyśmy nawet tylko szeptem lub nawet nie otwierając ust przemawiali samym milczeniem, to w głębi duszy krzyczymy. Przecież Bóg słyszy bez żadnej przeszkody wewnętrzny głos naszego serca" ${ }^{71}$.

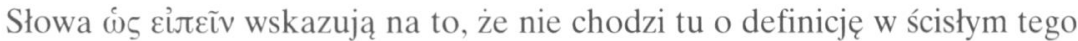
słowa znaczeniu, ile raczej o próbę definicji. Tłumaczenie wyrazu ó $\mu \iota \lambda i \alpha$ jako „rozmowa” byłoby znacznym zawężeniem, ponieważ rzeczownik ten oznacza: przebywanie razem, obcowanie z kimś; rozmowę, naukę; użycie, używanie; towarzystwo, zgromadzenie, grono ${ }^{72}$. Zresztą dopowiedzenie Klemensa, że możemy przemawiać „,samym milczeniem” i że „Bóg słyszy głos naszego serca”, wskazuje na to, że wyraz ó $\mu \lambda i \alpha$ nie tylko oznacza „rozmowę” z Bogiem, ale przede wszystkim „obcowanie z Bogiem”, nastawienie i otwarcie się na Boga $^{73}$. Ta łączność z Bogiem powinna być stała, czyli trwająca nieprzerwanie, w zależności zresztą od stopnia udoskonalenia. Chrześcijanin na etapie

${ }^{69}$ Stromata VII 39, 6, GCS 17, 30, Niemirska-Pliszczyńska II 248-249. Określenie to przyjął od Klemensa Ewagriusz Pontyjski (Orationes 3) oraz Jan Kasjan (Collationes Patrum IX 18,1).

${ }^{70}$ Por. E. Severus, Gebet, RACh VIII 1207-1209.

71 Stromata VII 39, 6, GCS 17, 30, Niemirska-Pliszczyńska II 248-249.

72 Por. Abramowiczówna III 276; Liddell-Scott 1222: ,intercourse, company; communion or intercourse with one"

73 Por. Stromata VII 43, 5. 
dojrzałej agape modli się, czyli pozostaje w egzystencjalnej łączności z Bogiem nawet podczas zwykłych czynności dnia codziennego, ,czy to zażywając space$\mathrm{ru}$, czy będąc w towarzystwie, czy to wypoczywając lub czytając, a nawet w czasie pełnienia rozsądnych zajęć ${ }^{74}$.

Tego rodzaju postulat ciągłej modlitwy, która w zasadzie powinna trwać przez całe życie ${ }^{75}$, wyklucza nawet jej zawężenie tylko do dialogu słownego. Bo jeśli nawet podczas spaceru moglibyśmy się modlić słowami, to przecież czytając nie możemy żadną miarą wymawiać - choćby w myślach - słów modlitwy. Dla Klemensa ,nawet sama wiara, że się coś uzyska, jest swego rodzaju modlitwą" ${ }^{, 76}$. Nadto rodzajem modlitwy jest też odtrącenie $\mathrm{zła}^{77}$. W zasadzie więc można by powiedzieć, jak to już wcześniej zauważył G. Békés ${ }^{78}$, że cała egzystencja gnostyka zatopionego w Bogu przez agape jest bezustanną modlitwą.

Tak pojęta modlitwa prowadzi do coraz pełniejszego zżycia z Bogiem, do

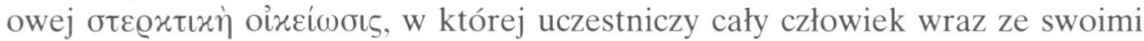
uczuciami. Przez pryzmat naszej wspólnoty z Bogiem mamy dostrzegać drugiego człowieka, uczestnika tejże wspólnoty. Kochając Boga w Trójcy Świętej jedynego z całej siły, umysłem, sercem i wolą, aprobujemy również w pełni i miłujemy to, co jest efektem Jego działalności: całe dzieło stworzenia, nie wykluczając nikogo ani niczego. Dlatego, jak pisze Klemens, doskonały chrześcijanin, który osiągnął wspólnotę życia z Bogiem, nie jest nawet „zdolny żywić nienawiści w stosunku do jakiegokolwiek ze stworzeń Bożych [...] kocha Stwórcę poprzez stworzenie"79, a wśród nich człowieka o tyle więcej od innych stworzeń, o ile je przewyższa, jako „stworzony na obraz i podobieństwo Boże" ${ }^{80}$; „świadczy miłość w stosunku do podobnego sobie rodzaju ludzkiego ze względu na miłość do Stwórcy”81; ,z miłości do Pana miłuje bliźniego"82.

Autentyczna wspólnota życia zakłada pełne uczestnictwo we wszystkich wartościach całej grupy i jej poszczególnych członków. Wspólnota to wymiana wartości, czyli dzielenie się nimi, to wrażliwość na „potrzeby towarzyszy”. Miłość według Klemensa jest „gorliwością w przyjaźni i serdecznością wraz z rozumną troską o potrzeby bliźnich" ${ }^{83}$. Wydaje się, że pojęcie przyjaźni już w pewnym stopniu suponuje obowiązek dzielenia się posiadanymi dobrami

74 Stromata VII 49, 7, GCS 17, 37, Niemirska-Pliszczyńska II 257.

75 Stromata VII 40. 3, GCS 17, 30, Niemirska-Pliszczyńska II 249.

76 Stromata VII 41, 8, GCS 17, 31, Niemirska-Pliszczyńska II 250.

77 Por. Stromata VII 39, 4.

${ }^{78}$ Por. De continua oratione Clementis Alexandrini doctrina, Roma 1942, s. 94: ,,affirmantes continuam orationem Clementis esse, ipsam existentiam christiani gnostice perfecti, ipsum gnosticum perfectum"; zob. też Stromata VII 73, 1.

79 Stromata VI 71, 4-5, GCS 52, 467, Niemirska-Pliszczyńska II 153-154.

80 Stromata IV 93, 3, GCS 52, 289.

81 Stromata II 86, 7, GCS 52, 159, Niemirska-Pliszczyńska I 187.

82 Stromata IV 75, 2, GCS 52, 282, Niemirska-Pliszczyńska I 338; por. III 54, 3-4.

83 Stromata II 41, 2, GCS 52, 134, przekład własny. 


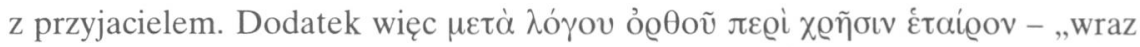
z rozumną troską o potrzeby towarzyszy", miał na celu zaakcentować bądź to zachowanie rozsądku i właściwej proporcji w dzieleniu się z innymi, bądź też wyodrębnienie dobroczynności jako elementu specjalnie ważnego, jakby konstytutywnie przynależnego do miłości chrześcijańskiej. Ta pierwsza ewentualność nie wchodzi w rachubę, ponieważ Klemens w dziele Który człowiek bogaty może być zbawiony na kanwie wypowiedzi z 1Kor 13, 5 powiedział, że ,agape nie szuka swego, ale rozlewa się na braci, o nich się trwoży, dla nich mądre szaleństwa popełnia" ${ }^{84}$. Na uwagę zasługuje wyrażenie: $\sigma \omega \phi \varrho o ́ v \omega \varsigma ~ \mu \alpha i v \varepsilon \tau \alpha$, dosłownie: „mądrze szaleje”, w którym można by dopatrzyć się sprzeczności

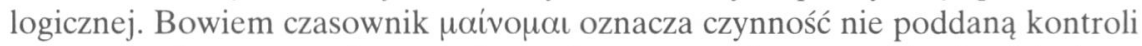

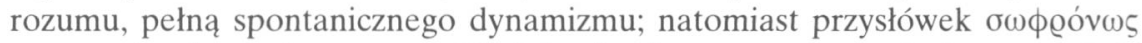
wprowadza kontrolę rozumu. Wydaje się, że przez tego rodzaju wypowiedź Klemens chciał zaakcentować potrzebę współdziałania czynnika rozumowego z uczuciowym, przy czym ten pierwszy nie powinien w niczym osłabiać rozmachu i dynamizmu związanego ze sferą emocjonalną. Dlatego właśnie agape „trwoży się o brata” i to uczucie troski mobilizuje wolę do działania.

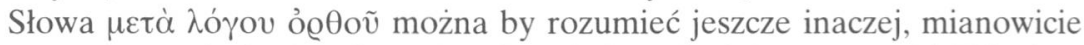
jako postulat mądrej selekcji w zakresie świadczenia dobroczynności. Zdaniem Klemensa, należy zwrócić uwagę na hierarchię wartości potrzeb naszych bliźnich. Najważniejsza jest pomoc w sprawach przynależnych do sfery duchowej człowieka, np. najlepszym działaniem, według Klemensa, na korzyść drugiego są pouczenia ${ }^{85}$ o prawach Bożych, które zbliżą go do doskonałej miłości.

Należy zwrócić uwagę, że agape, która uwrażliwia na potrzeby towarzyszy oraz pobudza do dobroczynności, nie może być utożsamiana z nią. Dobroczyn-

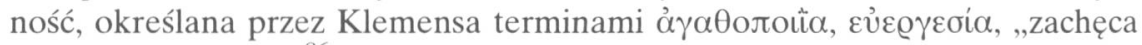

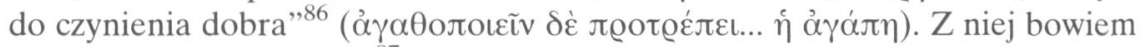
„wykwitają dobre czyny" ${ }^{87}$. Agape jest źródłem motywacji do dobrego działania, lecz w żadnym wypadku nie można postawić znaku równości między tymi obiema wartościami.

Klemens przypomina, że sama idea dobroczynności nie jest czymś, co stworzyło dopiero chrześcijaństwo:

„Wyrzeczenie się majątku, aby rozdzielić go między ubogich albo oddać ojczyźnie, nie jest czymś nowym: wielu ludzi przed przyjściem Zbawiciela to czyniło; jedni, by móc lepiej czas poświęcić martwej mądrości, inni dla marnego rozgłosu i próżnej żądzy sławy, tacy np. jak Anaksagoras, Demokryt czy Krates" ${ }^{\prime 8}$.

\footnotetext{
${ }^{84}$ Quis dives salvetur 38, 1, GCS 17, 184, Czuj s. 105.

85 Por. Stromata VII 53, 5.

86 Stromata VII 79, 1, GCS 17, 56, Niemirska-Pliszczyńska II 281.

87 Quis dives salvetur 28, 4, GCS 17, 187, Czuj s. 92.

88 Tamże 11, 4, GCS 17, 167, Czuj s. 60.
} 
Prawdziwie zasługującą wobec Boga jest ta dobroczynność, która została oparta na motywacji religijnej. Prawdziwą zasługę zdobywamy, gdy dajemy bliźniemu, w którym widzimy Chrystusa ${ }^{89}$ gdy liczymy tylko na nagrodę w niebie ${ }^{90}$, tzn. wtenczas, gdy jest w nas chociaż jakiś zaczątek agape. Stąd Pawłowe: „Gdybym cały swój majątek rozdał na żywienie ubogich i własne ciało wydał na spalenie, a miłości bym nie miał, nic mi nie pomoże" ${ }^{91}$. W tej wypowiedzi nader jasno wyróżnia się agape i dobroczynność jako dwie autonomiczne wartości. Dobroczynność może wystąpić tam, gdzie nie ma miłości, ale nie odwrotnie. Bowiem każda autentyczna miłość skłania nieodparcie do dobrych czynów. Podobnie też agape i dobroczynność mają różne zakresy. Dobroczynność chrześcijańska winna obejmować wszystkich ludzi bez wyjątku. W opozycji do partykularyzmu żydowskiego twierdzi Klemens, że:

„Chrystus nie przesądził, tak jak to czynili Żydzi, że bliźnim jest tylko krewny, współrodak, prozelita lub ktoś, kto jest także obrzezany albo posługuje się tym samym prawem" 92 .

Najlepszą ilustracją tego poglądu jest opowieść o miłosiernym Samarytaninie (Łk 10, 30-37), na którą Klemens w swym wykładzie się powołuje. Zatem dobrze czynić należy wszystkim ludziom bez wyjątku. Wrogom i przyjaciołom, chrześcijanom i niechrześcijanom ${ }^{93}$

Natomiast we wspólnocie miłości jesteśmy tylko z tymi, którzy do tej wspólnoty się włączyli poprzez przyjęcie chrztu i kodeksu moralnego Chrystusa oraz w niej trwają. Kiedy Klemens mówi, że agape jest „gorliwością w przyjaźni i serdeczności wraz z rozumną troską o potrzeby towarzyszy", dodaje:

„A towarzysz, to drugie ja. Dlatego nazywamy braćmi tych, których powtórnie powolał do życia ten sam Logos" $"$.

Rozumna troska o potrzeby członków tej samej wspólnoty to staranie o wspólne dobro wszystkich, którzy razem, jako jeden organizm, mają wzrastać na miarę dojrzałości Chrystusowej. Chrześcijańska miłość w swym aspekcie egzystencjalnym obejmuje przede wszystkim tych, którzy wszczepili się w Chrystusa i w Nim wspólnie wzrastają.

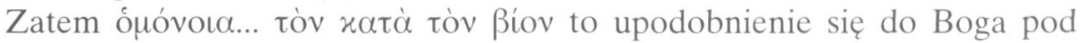
względem Jego troski o innych. Według określenia Klemensa ,niewypowie-

${ }^{89}$ Por. Stromata II 73, 1; III 54, 3-4.

90 Por. tamże III 56, 2; IV 36, 4.

911 Kor 13, 3 w thum. J. Czerskiego w Biblii Poznańskiej; por. Stromata VII 59, 4.

92 Quis dives salvetur 28, 1-2, GCS 17, 178, Czuj s. 91

93 Por. Stromata II 102, 4; zob. Wj 22, 21; 23, 9; Kpł 19, 33

94 Stromata II 41, 2, GCS 52, 134, Niemirska-Pliszczyńska I 157. Etymologia Klemensa do-

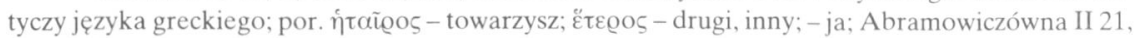
322. 
dziana jest miłość Boga do człowieka" "95. Miłość ta zgodnie ze swoją naturą przejawia się w licznych dobrodziejstwach, jakie Bóg wyświadczył i nadal świadczy ludziom. Całe dzieło stworzenia i odkupienia jest wyrazem miłości Boga, który „dla nas”, ludzi, stał się człowiekiem ${ }^{96}$, który „w ogromie swej miłości ku człowiekowi cierpiał zgodnie z naturą wszystkich ludzi”, który jak Ojciec pełen życzliwości „nie zaprzestaje upominać, ostrzegać, wychowywać, miłować"97.

Jeśli człowiek ma się upodobnić do Boga, to powinien czynić to pod każdym względem, również w tym zakresie, aby na wzór Boga kochać drugiego człowieka. Właśnie od Boga „uczymy się miłości do człowieka”. Dzięki której „nabywamy podobieństwa do Boga" ", bo miłość czyni dobrze „działając ściśle według wizerunku Boga"99. Doskonałość gnostyka polega m.in. „na trwającej nieustannie dyspozycji do dobrego działania, na podobieństwo Boga”. Bo „w rzeczywistości człowiek jest obrazem Boga, gdy dobrze czyni”100. "O

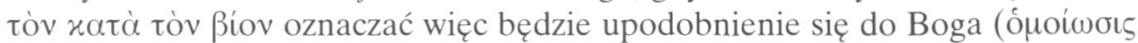
$\tau \tilde{\omega} \Theta \varepsilon \tilde{\omega})$ poprzez zażyłe przebywanie z Nim w modlitwie i wytworzenie w sobie stałej dyspozycji i gotowości do dzielenia się z innymi posiadanymi wartościami na wzór Boga, który pierwszy przyjął nas do swej wspólnoty życia i ubogacił swymi wartościami. Miłość to otwarcie naszej egzystencji dla Boga i dla drugich wraz ze stała troską i gotowością do działania na rzecz dobra naszych współbraci, wespół z którymi przynależymy do Jednego Ciała ${ }^{101}$.

Ojciec Święty akcentuje z jednej strony, że miłość jest uczuciem (i ,,jest ona ostatecznie uczuciem: quaedam animi affectio, które może być lub nie być, lecz które nie może być stworzone przez wolę"102, z drugiej strony dodaje, że nie można jej tylko redukować do uczucia: „W procesie spotkania pokazuje się również wyrażenia, że miłość nie jest tylko uczuciem. Uczucia przychodzą i odchodzą"103.

Głosząc prawdę o jednej miłości, w której eros i agape pozostają w harmonijnym zespoleniu ${ }^{104}$, Ojciec Święty zwraca uwagę na zakłócenia tej równowagi, które dokonują się przez jednostronną gloryfikację erosu (4). Z tej racji eros potrzebuje - jak stwierdza wielokrotnie Benedykt XVI - „dyscypliny i oczyszczenia” (4). „Konieczne jest oczyszczenie i dojrzewanie, które osiąga się

\footnotetext{
95 Protrepticus 104, 3, GCS 12, 72.

96 Por. Paedagogus I 62, 1; Quis dives salvetur 37, 2.

97 Paedagogus I 62, 2; Protrepticus 94, 1, GCS 12126 i 68.

98 Paedagogus I 99, 1, GCS 12 149; por. Gregorius Nazianzenus, Oratio 14, 27.

99 Stromata IV 113, 4, GCS 52, 298, Niemirska-Pliszczyńska I 360.

100 Stromata VI 60, 3; 102, 2, GCS 52, 462 i 169, przekład własny.

101 Por. Paedagogus I 18, 4; Stromata IV 55, 4; 66, 3; Kol 3, 12; 14, 15.

102 Deus caritas est 16, AAS 98 (2006) 230, wyd. Pallottinum, s. 24.

103 Tamże 17, AAS 98 (2006) 231, wyd. Pallottinum, s. 25.

104 Por. paragrafy 7-9.
} 
także na drodze wyrzeczenia. Nie jest to odrzuceniem erosu, jego «zatruciem», lecz jego uzdrowieniem w perspektywie jego prawdziwej wielkości”"105. Eros „wymaga ascezy, wyrzeczeń, oczyszczeń i uzdrowień”106.

Klemens unika stosowania terminu eros na określenie miłości chrześcijańskiej. Dopuszcza jednak określenia: „przyjaźń” ( $\phi \iota \lambda i \alpha)$ oraz „,serdeczność” (

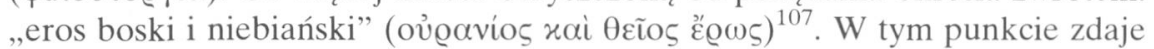
się prezentować stanowisko podobne do nauki Benedykta XVI.

Dalszą zbieżność można dostrzec w nauce o funkcji modlitwy, jako czynnika budującego miłość. Zdaniem Ojca Świętego, tylko człowiek napełniony miłością Boga, poprzez obcowanie z Nim, może „otrzymaną” miłość dalej przekazywać (7). Miłość bliźniego, stwierdza Ojciec Święty, ,może być urzeczywistniona jedynie wtedy, kiedy jej punktem wyjścia jest intymne spotkanie z Bogiem”108. Miłość do człowieka „karmi się spotkaniem z Chrystusem” (34). „Modlitwa, jako sposób czerpania wciąż na nowo sił od Chrystusa, staje się całkiem konkretną koniecznością"109.

Dalszą wyraźną tendencją, występującą w nauczaniu papieskim, jest wielokrotnie akcentowana prawda o tym, że miłość w swej istocie jest jedna. Daje się to zauważyć już w sformułowaniu tytułu pierwszej części jego encykliki: „Jedność miłości w stworzeniu i historii zbawienia”. Do tej idei Ojciec Święty powraca, kiedy mówi o ,jednej rzeczywistości miłości" ${ }^{110}$, lub kiedy stwierdza wprost „ "miłość» W gruncie rzeczy jest jedną rzeczywistością, ale mającą różne wymiary” (8). Podobnie Klemens akcentuje, że miłość jest ,jedna” $(\mu i \alpha)^{111}$,

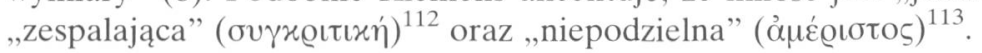

Dalszą paralelę w doktrynie Klemensa Aleksandryjskiego i Benedykta XVI można dostrzec w nauce o dobroczynności, która nierozłącznie związana jest z miłością. Tej problematyce poświęcił Ojciec Święty całą część drugą swej encykliki pt. „Caritas dzieło miłości dokonywane przez Kościół jako «wspólnota miłości»".

Szczupłe ramy niniejszego artykułu nie pozwalają na snucie dalszych szczegółowych dywagacji, na temat zbieżności występujących w nauce obu, wyżej omawianych, autorów. Dla ścisłości należy jednak dodać, że obok zbieżności i podobieństw, daje się zauważyć również różnice, w obu wykładach, dotyczące

\footnotetext{
105 Tamże 5, AAS 98 (2006) 221, wyd. Pallottinum, s. 8.

106 Tamze 5, AAS 98 (2006) 222, wyd. Pallottinum, s. 10.

107 Protrepticus 117, 2, GCS 12, 82.

108 Deus caritas est 18, AAS 98 (2006) 232, wyd. Pallottinum, s. 26-27.

109 Tamże 36, AAS 98 (2006) 248, wyd. Pallottinum, s. 54.

110 Tamże 7, AAS 98 (2006) 223, wyd. Pallottinum, s. 11.

111 Por. Protrepticus 88, 2, GCS 12, 65.

112 Por. Stromata V 15, 4, GCS 52, 335.

113 Por. Stromata II 87, 2, GCS 52, 159.
} 
nie tyle odmienności merytorycznych, ile specyficznych priorytetów doktrynalnych. Zasadniczą różnicę, daje się zauważyć, w stosowanej przez obu autorów terminologii. Klemens Aleksandryjski, wierny tradycji biblijnej, dość konsekwentnie stosuje na określenie miłości chrześcijańskiej terminu agape oraz jego formę czasownikową $\alpha \gamma \alpha \pi \alpha$ á . Odpowiednikami tych terminów na gruncie łacińskim są rzeczowniki: caritas, charitas, dilectio oraz czasownik diligere.

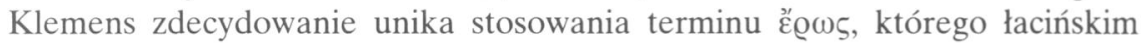
odpowiednikiem jest rzeczownik amor oraz jego forma czasownikowa amo. Benedykt XVI w swej encyklice stosuje na oznaczenie miłości chrześcijańskiej zarówno terminy: caritas, dilectio, diligere, jak i określenia: amor, amare. Co więcej, te dwa ostatnie terminy, najczęściej pojawiają się w łacińskim tekście jego encykliki. Można przypuszczać, że Ojciec Święty tak postępując, pragnie podkreślić jedność miłości, która może być różnie określana. Daje się tu zauważyć wpływ Pseudo-Dionizego Areopagity, bądź Augustyna, według którego nie terminy słowne, lecz intencja wewnętrzna kochającego, zwrócona ku dobru lub złu, decydują o tym, czy jego miłość jest autentyczna czy nie. Stąd Augustyn mówi o „miłości dobrej” i „miłości złej”, posługując się tym samym terminem amor $^{114}$; podobnie postępuje Pseudo-Dionizy Areopagita ${ }^{115}$.

Dalsze zróżnicowanie daje się zauważyć w doborze odmiennych aspektów merytorycznych, i co za tym idzie, różnych preferencji doktrynalnych. Benedykt XVI bardziej akcentuje w swym nauczaniu aspekt teocentryczny oraz genetyczno-dynamiczny miłości. Bóg, będący pełnią miłości, jest zarazem jej istotnym źródłem. Każdy, kto jednoczy się z Bogiem, zostaje napełniony Jego miłością. Miłość ta jawi się jako boska moc Ducha Świętego, która jednoczy serca wszystkich wierzących z sercem Bożym. „Duch bowiem - pisze Ojciec Święty - objawia się jako wewnętrzna moc (interior potestas), która harmonizuje serca [wierzących] z sercem Chrystusa i uzdalnia ich do miłowania braci tak, jak On ich umiłował"116. „Duch jest także mocą (vis), która przemienia serce wspólnoty Kościelnej, aby była w świecie świadkiem miłości Ojca, który chce uczynić z ludzkości jedną rodzinę w swoim Synu"117.

Klemens Aleksandryjski w swej definicji miłości, zwraca bardziej uwagę na jej aspekt strukturalno-finalny. Miłość obejmująca człowieka w całej jego psycho-fizycznej złożoności, zaprowadza stan harmonijnej jedności z Bogiem i bliźnimi. Doskonała, Bosko-ludzka wspólnota życia, jest efektem finalnym działania miłości. Aspekt dynamiczno-genetyczny, został w definicji Klemensa słabo uwzględniony. Nie mniej jednak wszystkie elementy nauczania papieskiego, można odnaleźć w szerokim kontekście doktrynalnym Klemensowej definicji.

114 Por. De civitate Dei XIV 7, 2, CCL 48, 421-422.

115 Por. De divinis nominibus IV, 11, PG 3, 708, tłum. M. Dzielska: Pseudo-Dionizy Areopagita, Pisma teologiczne, Kraków 2005, 253-254.

116 Deus caritas est 19, AAS 98 (2006) 233, wyd. Pallottinum, s. 29.

117 Tamże. 
LA DEFINIZIONE DELL'AMORE CRISTIANO DI CLEMENTE ALESSANDRINO NELLA LUCE DELLA ENCICLICA DI BENEDETTO XVI „DEUS CARITAS EST”

(Riassunto)

Tutti gli elementi dell'insegnamento del santo padre si può ritrovare nel largo contesto dottrinale della definizione di Clemente Alessandrino. Entrambi autori sottolineano unanimemente che l'amore proviene da Dio e conduce a Dio; è una e divina; abbraccia l'uomo intero: la sua sfera intelettuale, quella morale e della volontà, e anche emotivo e esistenziale. L'amore è inseparabilmente collegata con beneficenza. Indicando le differenze, ci vuole sottolineare, che Clemente Alessandrino abbastanza rigorosamente riserva il termine $\alpha \gamma \alpha \dot{\jmath}\rceil \eta$ per definire l'amore cristiano, evitando la parola ع́g $\omega \varsigma$; Benedetto XVI rompe questa distanza, introducendo

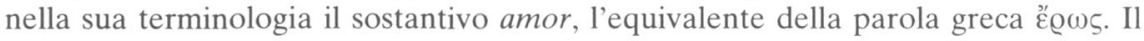
santo padre molto di più sottolinea nel suo insegnamento l'aspetto teocentrico e anche genetico e dinamico dell'amore. Clemente di Alessandria nella sua definizione di questa realtà mette l'accento di più sull'aspetto strutturale e finale. 